\title{
ARTICLE
}

\section{Migration in the UNFCCC Workstream on Loss and Damage: An Assessment of Alternative Framings and Conceivable Responses}

Benoit Mayer*

First published online 6 April 2016

\begin{abstract}
Discourses on 'climate migration' have played an instrumental role in initiating negotiations on loss and damage under the United Nations Framework Convention on Climate Change (UNFCCC). Yet, to date, the framing of climate migration has not been clear: it has been considered as a tool for reducing loss and damage (hence essentially a form of adaptation) or, alternatively, as a source of loss and damage for the migrants or for other concerned communities. Moreover, proposed approaches to address climate migration as a form of loss and damage have extended beyond compensation, and remain controversial among developed nations. In the highly politicized field of migration governance, however, this article submits that policy support and guidance in addressing loss and damage could prompt dangerous forms of political interference, such as the imposition of a Western objective of containing migrants to the Global South. It is thus suggested that top-down migration policies may not help vulnerable nations who face loss and damage in the context of climate migration.
\end{abstract}

Keywords: Climate change, Migration, Loss and damage, Warsaw International Mechanism on Loss and Damage, UNFCCC Workstream on Loss and Damage, Paris Agreement

\section{INTRODUCTION}

Empirical as well as theoretical migration studies published over the last two decades have established that environmental change has an impact on human mobility, in particular within states, and that this has been exacerbated by the impacts of climate change. ${ }^{1}$ These studies suggest that rather than creating a distinct population of

* Wuhan University, Faculty of Law, International Law Institute and Environmental Law Institute, Wuhan (China).

Email: bnt.mayer@gmail.com.

1 For a review see, e.g., J. Morrissey, 'Rethinking the "Debate on Environmental Refugees": From "Maximilists and Minimalists" to "Proponents and Critics"' (2012) 19 Journal of Political Ecology, pp. 36-49. 
'climate refugees', environmental change is a diffuse and indirect factor affecting migration 'through its influence on a range of economic, social and political drivers'. ${ }^{2}$ Political narratives on 'climate migration' have developed, often through a simplification of these findings, to plead for, among other things, climate change mitigation and reforms in migration governance. Yet, the exact definition or framing of climate migration remains unclear. Within the global climate change negotiations pursued under the United Nations Framework Convention on Climate Change (UNFCCC), ${ }^{3}$ migration has been discussed as a way for communities to adjust to the impacts of climate change (adaptation) ${ }^{4}$ and it has also been a central theme in the workstream on 'approaches to address loss and damage associated with climate change impacts in developing countries that are particularly vulnerable to the adverse effects of climate change'. ${ }^{5}$

The concept of 'loss and damage' remains equally vague and ill-defined despite years of negotiations. The UNFCCC Secretariat proposed a working definition which included 'the actual and/or potential manifestation of impacts associated with climate change ... that negatively affect human and natural systems' ${ }^{6}$ Loss and damage include the harm caused by climate change adaptation (such as expenses and unintended consequences) as well as unavoidable (or unavoided) harm. ${ }^{7}$ An important challenge for this conceptual development relates to the attribution of specific weather or climate events to intensive anthropogenic greenhouse gas (GHG) emissions, ${ }^{8}$ but frameworks on probabilistic event attribution under development could help to overcome this challenge. ${ }^{9}$ An additional source of difficulty,

2 Foresight Agency, 'Migration and Global Environmental Change: Final Project Report', UK Government Office for Science, 2011, p. 9, available at: https:/www.gov.uk/government/uploads/system/uploads/ attachment_data/file/287717/11-1116-migration-and-global-environmental-change.pdf (Foresight Report).

3 New York, NY (US), 9 May 1992, in force 21 Mar. 1994, available at: http://unfccc.int/resource/docs/ 2009/cop15/eng/11a01.pdf.

4 Decision 1/CP.16, 'The Cancún Agreements: Outcome of the Work of the Ad Hoc Working Group on Long-term Cooperative Action under the Convention', UN Doc. FCCC/CP/2010/7/Add.1, 15 Mar. 2011, para. 14(f), available at: http://unfccc.int/resource/docs/2010/cop16/eng/07a01.pdf.

5 Decision 3/CP.18, 'Approaches to Address Loss and Damage Associated with Climate Change Impacts in Developing Countries that are Particularly Vulnerable to the Adverse Effects of Climate Change to Enhance Adaptive Capacity', UN Doc. FCCC/CP/2012/l.4/Rev.1, 8 Dec. 2012, para. 7(a)(vi), available at: http://unfccc.int/documentation/documents/advanced_search/items/6911.php?priref=600007270; Decision 1/CP.21, 'Adoption of the Paris Agreement', UN Doc. FCCC/CP/2015/L.9, 12 Dec. 2015, para. 50, available at: http://unfccc.int/resource/docs/2015/cop21/eng/109.pdf.

6 UNFCCC Secretariat, 'A Literature Review on the Topics in the Context of Thematic Area 2 of the Work Programme on Loss and Damage: A Range of Approaches to Address Loss and Damage Associated with the Adverse Effects of Climate Change', UN Doc. FCCC/SBI/2012/INF.14, 15 Nov. 2012, para. 2, available at: http://unfccc.int/resource/docs/2012/sbi/eng/inf14.pdf (UNFCCC Literature Review).

7 Cf. Decision 2/CP.19, 'Warsaw International Mechanism [WIM] for Loss and Damage Associated with Climate Change Impacts', UN Doc. FCCC/CP/2014/L.2, 31 Jan. 2014, recital 5 ('loss and damage ... includes, and in some cases involves more than that which can be reduced by adaptation'), available at: http://unfccc.int/resource/docs/2013/cop19/eng/10a01.pdf.

8 If climate change increases the probability of certain weather events, it does not create weather events of a different nature.

9 P. Pall et al., 'Anthropogenic Greenhouse Gas Contribution to Flood Risk in England and Wales in Autumn 2000' (2011) 470(7334) Nature, pp. 382-5. See, however, M. Hulme, 'Attributing Weather Extremes to “Climate Change”: A Review' (2014) 38(4) Progress in Physical Geography, pp. 499-511. 
however, relates to the identification of social loss and damage attributable to these physical events. ${ }^{10}$ Physical effects of climate change produce social effects which, like the concentric circles produced by an impact on water, extend ad infinitum in time and space, through economic and other social processes. In these spheres of causality climate migration does not appear only as a consequence, but also as an intermediate factor for further social effects - in particular when migration leads to destitution or human rights abuses. Within migration and its multiple effects, identifying the adverse consequences of climate change inevitably involves value judgments. Migration is sometimes conceived as a normal or opportune social process of adaptation; at other times, it is depicted as harmful and unwanted.

In this article, I wish to question the desirability of including considerations of human mobility within the UNFCCC Workstream on Loss and Damage or in future actions based on this workstream. More specifically, I show some grounds for scepticism regarding the ability of global institutions to 'guide' domestic migration policies for the benefit of the populations of the most vulnerable developing states. On the one hand, migration comprises multifaceted and complex human practices: national migration policies need to be carefully devised as part of a holistic approach to development, and top-down one-size-fits-all 'solutions' could be counterproductive. On the other hand, it cannot be ignored that Western states have their own political agendas, including a strongly perceived interest in containing migration from the South, ${ }^{11}$ and that international guidance in addressing loss and damage could become a Trojan horse for a Western influence in the migration policies of the developing states most vulnerable to climate change impacts.

This article is structured as follows. Section 2 provides a general background by retracing the emergence of discussions on migration and loss and damage within the UNFCCC. Section 3 distinguishes and engages with three framings of migration as a way to reduce or, alternatively, as a source of loss and damage for either migrants themselves or for surrounding communities. Section 4 explores possible approaches to address migration aspects of loss and damage on the basis of proposals submitted to the UNFCCC, and Section 5 concludes.

\section{MIGRATION WITHIN THE CLIMATE REGIME: FROM 'ADAPTATION' TO 'LOSS AND DAMAGE'}

\subsection{The Climate-Migration Nexus}

Dominant migration theories during most of the $20^{\text {th }}$ century attributed human mobility typically to economic or political conditions. ${ }^{12}$ Starting in the mid to late

10 Lawyers have developed relevant reflections on the attribution of injury, in particular in the common law of tort, the civil law of extra-contractual responsibility, and the international law of state responsibility for internationally wrongful acts.

11 For a dated but strong theoretical discussion see B.S. Chimni, 'The Geopolitics of Refugee Studies: A View from the South' (1998) 11(4) Journal of Refugee Studies, pp. 350-74.

12 For an influential example see A. Lee, 'Theory of Migration' (1966) 3(1) Demography, pp. 47-57. 
1980s, the relevance of environmental factors in migration became apparent in the context of a growing awareness of the interactions between human societies and their environment. ${ }^{13}$ As climate change has become one of the key environmental issues of our time, scholars and activists have promoted global governance reform to take climate migration into consideration. Their political agendas have diverged and extended to, among others, the protection of the rights of migrants, a reinforcement of efforts to mitigate climate change, humanitarian assistance to concerned communities, and even greater investment in border surveillance. ${ }^{14}$

Within the climate regime, the climate-migration nexus was first considered by the Ad Hoc Working Group on Long-Term Cooperative Action under the Convention (AWG-LCA), as part of a process launched by the 2007 Bali Action Plan (COP-13) in order to, among other objectives, 'enhance ... action on adaptation'. ${ }^{15}$ Such discussions were promoted largely by developing states as an argument in favour of North-South climate finance. ${ }^{16}$ As a result of these discussions, subparagraph 14(f) of the 2010 Cancún Agreements (COP-16) called on all parties to take ' $[\mathrm{m}]$ easures to enhance understanding, coordination and cooperation with regard to climate change induced displacement, migration and planned relocation, where appropriate, at national, regional and international levels'. ${ }^{17}$ This provision dissipated any doubts about the possibility of framing relevant migration policies as adaptation, and made them eligible for dedicated technical or financial assistance. ${ }^{18}$ While promoting migration as a viable policy option, ${ }^{19}$ subparagraph $14(\mathrm{f})$ also helped to put the climate-migration nexus on the agenda of various research and advocacy institutions. Nevertheless, as Koko Warner noted, this provision did not fully satisfy some of its advocates because it 'framed [migration issues] as matters for cooperation, rather than issues of fault, liability, or legality'. ${ }^{20}$

13 See generally E. Piguet, "From "Primitive Migration" to "Climate Refugees": The Curious Fate of the Natural Environment in Migration Studies' (2013) 103(1) Annals of the Association of American Geographers, pp. 148-62.

14 See generally B. Mayer, “"Environmental Migration” as Advocacy: Is It Going to Work?’ (2014) 29(2) Refuge, pp. 27-41.

15 Decision 1/CP.13, 'Bali Action Plan', UN Doc. FCCC/CP/2007/6/Add.1, 14 Mar. 2008, para. 1(c), available at: http://unfccc.int/resource/docs/2007/cop13/eng/06a01.pdf.

16 K. Warner, 'Human Migration and Displacement in the Context of Adaptation to Climate Change: The Cancún Adaptation Framework and Potential for Future Action' (2012) 30(6) Environment and Planning C: Government and Policy, pp. 1061-77.

17 Decision 1/CP.16, n. 4 above, para. 14(f). The Cancún Agreements do not contain any definition of 'migration' and 'displacement'. A subsequent UNFCCC technical paper reflects a general understanding that 'migration tends to refer to voluntary movement, while displacement tends to refer to forced movement': UNFCCC Secretariat, Technical Paper, 'Non-Economic Losses in the Context of the Work Programme on Loss and Damage', UN Doc. FCCC/TP/2013/2, 9 Oct. 2013, para. 82, available at: http://unfccc.int/resource/docs/2013/tp/02.pdf (UNFCCC Technical Paper).

18 Adaptation remains heavily underfunded in comparison with migration: see, e.g., B Buchner et al., 'The Global Landscape of Climate Finance 2014', Climate Policy Initiative, Nov. 2014, available at: http://climatepolicyinitiative.org/wp-content/uploads/2014/11/The-Global-Landscape-of-Climate-Finance2014.pdf.

19 K. Warner et al., 'National Adaptation Plans and Human Mobility' (2015) 49 Forced Migration, pp. 8-9.

20 Warner, n. 16 above, p. 1066. 


\subsection{The UNFCCC Workstream on Loss and Damage}

Claims for the responsibility of developed nations towards those most severely affected by climate change impacts are nothing new. ${ }^{21}$ Taking a prominent part in the 'blame game' of the early 1990s, Malaysia's Prime Minister Mahathir Mohamad contrasted the 'pittance' offered by Western states as development assistance or promises of climate finance with the much greater 'loss of earnings by the poor countries'. ${ }^{22}$ In 1991, the Alliance of Small Island States (AOSIS) proposed the creation of an insurance mechanism funded by developed nations to 'compensate the most vulnerable small island and low-lying coastal developing countries for loss and damage resulting from sea level rise'. ${ }^{23}$ In lieu of such a mechanism, however, the UNFCCC formulated only a vague duty for developed states to 'assist the developing country Parties that are particularly vulnerable to the adverse effects of climate change in meeting costs of adaptation to those adverse effects'. ${ }^{24}$ Daniel Bodansky has attributed the disregard of the AOSIS proposal to the fact that the states most severely affected by climate change 'had [little] to offer the developed world in exchange for financial transfers'. 25

Clearer scientific evidence of the actual or predictable impacts of climate change on poorer communities, in the context of stalling international negotiations on climate change mitigation, led progressively to more sympathy for claims for climate change reparations among a larger number of developing states and nongovernmental organizations (NGOs). ${ }^{26}$ The 2007 Bali Action Plan (COP-13) contained a section inviting the AWG-LCA to consider 'means to address loss and damage associated with climate change impacts in developing countries that are particularly vulnerable to the adverse effects of climate change'. ${ }^{27}$ This topic, however, was largely sidelined in the work of the AWG-LCA by the attempt by developed states to 'avoid discussions related to proposals around compensation for

21 The responsibility of Western states had already been invoked by developing states in the Caracas Declaration of the Ministers of Foreign Affairs of the Group of 77 on the Occasion of the Twenty-Fifth Anniversary of the Group, 21-23 June 1989, para. II-34, available at: http://www.g77.org/doc/Caracas $\% 20$ Declaration.html.

22 Report of the United Nations Conference on Environment and Development (UNCED), Rio de Janeiro (Brazil), 3-14 June 1992, 'Statements by the Heads of State or Government at the Summit Segment of the Conference', UN Doc. A/CONF.151/26/Rev.1(Vol. III), p. 233.

23 UNFCCC Secretariat, 'Negotiation of a Framework Convention on Climate Change: Elements Relating to Mechanisms', UN Doc. A/AC.237/WG.II/CRP.8, 27 Dec. 1991, Submission by Vanuatu, 'Draft Annex relating to Insurance', p. 2. For a comparable proposal to the AWG-LCA, see UNFCCC Secretariat, 'Ideas and Proposals on the Elements Contained in Paragraph 1 of the Bali Action Plan: Submissions from Parties', UN Doc. FCCC/AWGLCA/2008/Misc.5/Add.2 (Part I), 10 Dec. 2008, AOSIS Submission, 'Multi-Window Mechanism to Address Loss and Damage from Climate Change Impacts', p. 24 (AOSIS 2008 Submission).

24 UNFCCC, n. 3 above, Art 4(4).

25 D. Bodansky, 'The United Nations Framework Convention on Climate Change: A Commentary' (1993) 18 Yale Journal of International Law, pp. 451-558, at 528.

26 Intergovernmental Panel on Climate Change (IPCC), Climate Change 2007 (AR4) (IPCC, 2007), available at: http://www.ipcc.ch/publications_and_data/publications_and_data_reports.shtml; N. Stern, The Stern Review on the Economics of Climate Change (Cambridge University Press, 2007).

27 Decision 1/CP.13, n. 15 above, para. 1(c)(iii). 
loss and damage ${ }^{28}$ by proposing an alternative focus on risk management, in particular through risk-sharing mechanisms and disaster risk-reduction strategies.

After three years and little progress, the 2010 Cancún Agreements (COP-16) established a 'work programme', assigned to the Subsidiary Body for Implementation (SBI), in order again 'to consider, including through workshops and expert meetings, as appropriate, approaches to address loss and damage associated with climate change impacts in developing countries that are particularly vulnerable to the adverse effects of climate change'. ${ }^{29}$ The Cancún Agreements also clarified that this work programme would cover 'the impacts related to extreme weather events and slow onset events', ${ }^{30}$ such as 'sea level rise, increasing temperatures, ocean acidification, glacial retreat and related impacts, salinization, land and forest degradation, loss of biodiversity and desertification'. ${ }^{31}$ While the Cancún Agreements emphasized the relevance of migration for adaptation, ${ }^{32}$ no connection was made between migration and loss and damage.

The 2011 Durban conference (COP-17) defined three thematic areas for the work programme on loss and damage: (i) assessing the risk of loss and damage; (ii) developing approaches to address loss and damage; and (iii) defining the role of UNFCCC negotiations. ${ }^{33}$ Building on the third theme, the 2012 Doha conference (COP-18) determined the role of the UNFCCC in relation to loss and damage as: (a) 'enhancing knowledge and understanding'; (b) 'strengthening dialogue, coordination, coherence and synergies'; and (c) 'enhancing action and support, including finance, technology and capacity-building' 34 While developed states continued to oppose any reference to 'redress' or 'compensation', they progressively agreed to redirect discussions on possible forms of technical or financial 'support' to the most vulnerable developing countries.

An important step was made in 2013 (COP-19) with the decision to establish the Warsaw International Mechanism for Loss and Damage Associated with Climate Change Impacts (WIM). ${ }^{35}$ Specific arrangements were adopted the following year at the Lima conference (COP-20), including the composition of the Executive Committee of the WIM, basic rules on procedure, and a two-year work plan. ${ }^{36}$ The work plan put emphasis on spurring research and raising awareness on factors of vulnerability, risk management approaches, the impacts of slow onset, non-economic

28 K. Warner \& S. Zakieldeen, 'Loss and Damage due to Climate Change: An Overview of the UNFCCC Negotiations', European Capacity Building Initiative, 2012, p. 4, available at: http://www.oxford climatepolicy.org/publications/documents/LossandDamage.pdf.$$
\text { Decision 2/CP 20, 'WIM for Loss and }
$$
cop20/eng/10a02.pdf. 
loss, resilience, migration, as well as financial instruments and tools. ${ }^{37}$ Recently, however, some developing states have taken a stronger position in favour of extending the mandate of the WIM (or that of a succeeding or additional institution) from its current role in, essentially, promoting a better understanding and greater awareness of loss and damage to an operational mission supported by a financial instrument. ${ }^{38}$

\subsection{Migration in the UNFCCC Workstream on Loss and Damage}

Migration has generally occupied a prominent place in the UNFCCC Workstream on Loss and Damage. The fear of massive arrivals of climate refugees in Western states (although scientifically unfounded) ${ }^{39}$ contributed to forging widespread support for the initiation of negotiations in this workstream, as addressing loss and damage was related to the strongly perceived interest of all states to avoid large inflows of migrants. ${ }^{40}$ The Doha conference (COP-18) recognized the importance of migration to the workstream and emphasized the need for 'enhancing the understanding of ... how impacts of climate change are affecting patterns of migration, displacement and human mobility'. ${ }^{41}$ Similarly, the workplan of the WIM calls for enhancing 'the understanding of and expertise on how the impacts of climate change are affecting patterns of migration, displacement and human mobility; and the application of such understanding and expertise'. ${ }^{42}$ Technical papers prepared by the UNFCCC Secretariat put a strong emphasis on migration, notably in relation to slow-onset events, ${ }^{43}$ to non-economic losses, ${ }^{44}$ and to approaches to address loss and damage. ${ }^{45}$

37 UNFCCC Secretariat, 'Report of the Executive Committee of the WIM for Loss and Damage associated with Climate Change Impacts', UN Doc. FCCC/SB/2014/4, 24 Oct. 2014, Annex II; and Decision 2/CP.20, ibid., para. 1.

38 See, e.g., the informal note of the Co-Chairs, 'Reflections on Progress Made at the Fourth Part of the Second Session of the Ad Hoc Working Group on the Durban Platform for Enhanced Action', ADP.2014.3.InformalNote, 17 Apr. 2014, p. 12, available at: http://unfccc.int/resource/docs/2014/ adp2/eng/3infnot.pdf (which reflects the demand of some parties to include in the Paris Agreement '[a] specific commitment to provide support for financing and operationalization of the WIM for Loss and Damage'). See also AOSIS, 'Submission of Nauru on behalf of AOSIS on its View on Loss and Damage in the 2015 Agreement', 4 Nov. 2014, p. 1, available at: http://www4.unfccc.int/submissions/ Lists/OSPSubmissionUpload/118_99_130596590736299152-AOSIS\%20Submission\%20on\%20Loss \%20and\%20Damage_NOV2014.pdf (AOSIS Nauru Submission) (noting that '[i]mmediate financial, technical and capacity building support that is adequate, provided on a timely basis and truly accessible will be required to address loss and damage in SIDS [small island developing states]. Financial flows from developed countries for addressing loss and damage in vulnerable developing countries should be new and additional to financing for mitigation and adaptation'). See generally Foresight Report, n. 2 above.

40 This is apparent in, for instance, the arguments framed in the Submission of 'Nauru on behalf of AOSIS: Views and Information on Elements to be Included in the Recommendations on Loss and Damage in accordance with Decision 1/CP.16', UN Doc. FCCC/SBI/2012/MISC.14, 8 Oct. 2012, p. 9, available at: http://unfccc.int/resource/docs/2012/sbi/eng/misc14.pdf; and AOSIS 2008 Submission, n. 23 above, para. 92 .

41 Decision 3/CP.18, n. 5 above, para. 7(a)(vi).

42 Report of the Executive Committee of the WIM, n. 37 above, Annex II, p. 11.

43 UNFCCC Secretariat, Technical Paper, 'Slow Onset Events', UN Doc. FCCC/TP/2012/7, 26 Nov. 2012, available at: http://unfccc.int/resource/docs/2012/tp/07.pdf.

44 UNFCCC Technical Paper, n. 17 above, paras 82-6.

45 UNFCCC Literature Review, n. 6 above, paras 110, 130. 'Migration' was one of the keywords selected by the Secretariat to conduct a literature review: ibid., para. 4 . 
Some of the most influential promoters of a workstream on loss and damage, such as Saleemal Huq and Koko Warner, have also flagged migration as one of the most pressing questions to address. ${ }^{46}$

Yet, initially at least, the inclusion of discussions on migration within the Workstream on Loss and Damage did not appear to be actively supported by any strong coalition of states. Until recently, the few references to migration in the party submissions to the workstream were relatively anecdotal. ${ }^{47}$ Strikingly, none of the party submissions on the drafting of the WIM workplan - including submissions by AOSIS, G77 and China, the Least Developed Countries group, and African Group of Negotiators - included any mention of migration. By contrast, discussions on migration within the loss and damage workstream have been actively promoted by non-parties, including some isolated $\mathrm{NGOs}^{48}$ and a loose coalition of specialized international organizations, NGOs and academic institutions. ${ }^{49}$

However, the negotiations during the second session of the Ad Hoc Working Group on the Durban Platform for Enhanced Action (ADP), in the run-up to COP-21, showed a new commitment by least developed and developing states to a 'climate change displacement coordination facility'. ${ }^{50}$ Developed states, which firmly opposed any mention of compensation or liability, showed some readiness to compromise on proposals for migration governance. ${ }^{51}$ In the Decision adopting the 2015 Paris Agreement, the parties requested the creation of a 'task force ... to develop recommendations for integrated approaches to avert, minimize and address

46 S. Huq, E.L. Roberts \& A. Fenton, 'Loss and Damage' (2013) 3(11) Nature Climate Change, pp. 947-9, at 948 ('Developing countries need guidance and support to implement approaches to ... address those impacts that cannot be avoided with a broader set of tools that may include risk transfer and risk retention measures, as well as policies to promote migration and facilitate resettlement'); and Warner, n. 16 above.

47 See the Submission of Bolivia (on behalf of Ecuador, China, El Salvador, Guatemala, Nicaragua, the Philippines, and Thailand) and Ghana, UN Doc. FCCC/SBI/2012/MISC.14/Add.1, 19 Nov. 2012, pp. 5 and 30, available at: http://unfccc.int/resource/docs/2012/sbi/eng/misc14a01.pdf.

48 E.g., Climate Action Network, 'Submission on the Workplan of the WIM on Loss \& Damage', 2 June 2014, para. 6, available at: http://climatenetwork.org/sites/default/files/can_submission_on_work plan_for_ld_mechanism_0.pdf; ACT Alliance, 'Annual Report 2014 - Full Life and Dignity: Justice Ahead for All in a Challenging Climate', available at: http://actalliance.org/wp-content/uploads/2015/ 07/ACT-Alliance-annual-report-2014.pdf; Brot für die Welt (Bread for the World), 'Submission on Loss and Damage Associated with Climate Change', 2012, p. 2, available at: http://unfccc.int/resource/ docs/2012/smsn/ngo/265.pdf.

49 See, e.g., Joint Submission from the Advisory Group on Climate Change and Human Mobility (International Organization for Migration (IOM), UNDP, UNHCR, UN University Institute for Environment and Human Security, Norwegian Refugee Council, Internal Displacement Monitoring Centre, Sciences-Po CERI, and Refugees International), 1 July 2014, available at: http://www.unhcr.org/542e94e69.pdf; Joint Submission by UNHCR, UN University, Norwegian Refugee Council, Special Rapporteur on the Human Rights of Internally Displaced Persons, and IOM, 19 Oct. 2012, UN Doc. FCCC/SBI/2012/MISC.14/Add.1, available at: http://unfccc.int/resource/docs/2012/sbi/eng/misc14a01.pdf.

50 See 'Submission of Nepal on behalf of the Least Developed Countries Group', 21 Oct. 2014, p. 4, available at: http://www4.unfccc.int/submissions/Lists/OSPSubmissionUpload/39_99_13058449981 7551043-Submission\%20by\%20Nepal\%20ADP_21\%20Oct\%202014.pdf; ADP, $2^{\text {nd }}$ Session, Pt 10, Working Document E, 3 Sept. 2015 at 23:30, p. 1, available at: https://unfccc.int/files/bodies/awg/ application/pdf/adp2-10_e_03sep2015t2330_wds.pdf. See generally J. Wentz \& M. Burger, 'Designing a Climate Change Displacement Coordination Facility: Key Issues for COP 21' (Columbia Law School, Sabin Center for Climate Change Law, Sept. 2015).

51 C. Arenas, 'A Climate Change Displacement Coordination Facility in the Paris Draft Agreement', Displacement Solutions, 6 Nov. 2015, available at: http://displacementsolutions.org/wp-content/ uploads/2015/11/Climate-change-displacement-coordination-facility.pdf. 
displacement related to the adverse impacts of climate change', ${ }^{52}$ while explicitly 'agree[ing]' that the mention of loss and damage in the Paris Agreement 'does not involve or provide a basis for any liability or compensation'. 53

\section{FRAMING MIGRATION IN RELATION TO LOSS AND DAMAGE}

In order to go beyond a vague connection between migration and loss and damage, this section distinguishes and engages critically with alternative framings of human mobility in documents before the UNFCCC workstream as, respectively, a way to reduce loss and damage or as a source of loss and damage, either for migrants themselves or for other concerned communities. These framings place emphasis on particular aspects of loss and damage in relation to particular migration scenarios. For instance, the framing of migration as loss and damage for the migrants themselves applies most convincingly to forced migration, whereas voluntary migration is more often depicted as a way of reducing loss and damage. Similarly, the expenses met by host communities through programmes to assist and protect incoming migrants can be framed alternatively as a way of addressing primarily non-economic loss and damage suffered by the migrants themselves, or as the largely economic loss and damage suffered by the host community as a consequence of migration (such as the costs of protection and assistance). However, even if these framings are not mutually exclusive in principle, they tend to suggest distinct responses to the growing momentum for action on climate migration.

\subsection{Migration as a Way of Reducing Loss and Damage}

Human mobility can be viewed as a way of reducing loss and damage associated with climate change impacts. Migration has always been a strategy of individuals, households, communities and societies to improve, avoid a degradation of, or otherwise adjust to changes in perceived living conditions. ${ }^{54}$ Thus, migration may either anticipate physical events (as where populations flee from a region in the expectation of an extreme weather event), or immediately follow the occurrence of a physical event in attempting to avoid greater loss and damage caused, in particular, by the destruction of the most basic infrastructures. Historical evidence confirms that migration occurs as a reaction to the deterioration in living conditions generated by the impacts of natural climatic changes. ${ }^{55}$ Relevant public policies in this context seek

52 Decision 1/CP.21, n. 5 above, para. 50.

53 Ibid., para. 52.

54 See, e.g., 'Report of the UN Special Rapporteur on the Human Rights of Migrants, François Crépeau, to the General Assembly', UN Doc. A/67/299, 13 Aug. 2012, available at: http://www.un.org/Docs/ journal/asp/ws.asp? $\mathrm{m}=\mathrm{A} / 67 / 299$.

55 See, e.g., A.N. Penna, The Human Footprint: A Global Environmental History (Wiley, 2010); W.J. Burroughs, Climate Change in Prehistory: The End of the Reign of Chaos (Cambridge University Press, 2005); Jin-Qi Fang \& Guo Liu, 'Relationship between Climatic Change and the Nomadic Southward Migrations in Eastern Asia during Historical Times' (1992) 22(2) Climatic Change, pp. 151-68; N. Pederson et al., 'Pluvials, Droughts, the Mongol Empire, and Modern Mongolia' (2014) 111(12) Proceedings of the National Academy of Sciences, pp. 4375-9; G. Parker, Global Crisis: War, Climate Change and Catastrophe in the Seventeenth Century (Yale University Press, 2013). 
either to protect migrants or to 'manage' migration through measures that include, for example, economic incentives, border surveillance, and forced resettlement.

It is therefore not surprising that mobility has been reported as a coping or adaptation mechanism in the context of climate change, prompting debates on appropriate policy responses. Diverse sets of dynamics have been discussed within the UNFCCC Workstream on Loss and Damage. For instance, a submission by Gambia (on behalf of the Least Developed Countries Group) highlighted that some farming households were increasingly turning to seasonal urban or cross-border mobility to cope with a drought which affected millet production. ${ }^{56}$ Similarly, a note prepared by the UNFCCC Secretariat reported a study on the contribution of migrant social networks in Mali, Mauritania and Senegal, which 'helped to build up social capital in order to increase social resilience in their communities of origin'. ${ }^{57}$ The same note also documented the issuing of transhumance certificates to pastoralists within the Economic Community of West African States (ECOWAS) to provide 'opportunities ... to cross borders for grazing and therefore to adapt to the challenges posed by climate change through seasonal mobility and migration'. 58

In terms of policy responses, however, the objective of reducing loss and damage cannot be distinguished clearly from existing efforts towards climate change adaptation. ${ }^{59}$ Framing migration as a way of reducing the exposure or the vulnerability of populations to adverse climate change impacts suggests only that migration should be encouraged as a form of adaptation to climate change a conclusion that had already been reached in the 2010 Cancún Agreements (COP-16) ${ }^{60}$ In order to make a useful contribution to climate governance, the Workstream on Loss and Damage needs to look beyond ways of reducing loss and damage and beyond adaptation. The preamble to the Decision establishing the WIM (COP-19) acknowledged that 'loss and damage associated with the adverse effects of climate change includes, and in some cases involves more than, that which can be reduced by adaptation'. ${ }^{61}$ The explicit inclusions of both what can and what cannot be reduced through adaptation implies that the loss and damage workstream is meant to suggest new types of response, possibly at a different level of governance. Such new responses are most persuasively conceived in relation to mechanisms that

56 'Submission by Gambia on behalf of the Least Developed Countries Group on Loss and Damage' (2013), p. 2, available at: https://unfccc.int/files/adaptation/application/pdf/submission_by_the_ gambia_on_behalf_of_the_least_developed_countries_on_loss_and_damage.pdf (referring to S. Yaffa, 'Loss and Damage from Drought in the North Bank Region of The Gambia', UN University Institute for Environment and Human Security, 2013).

57 UNFCCC Literature Review, n. 6 above, para. 110 (referring to J. Scheffran, E. Marmer \& P. Sow, 'Migration as a Contribution to Resilience and Innovation in Climate Adaptation: Social Networks and Co-development in Northwest Africa' (2012) 33(1) Applied Geography, pp. 119-27).

58 UNFCCC Literature Review, ibid., para. 130.

59 See, e.g., 'Submission of Norway, Work Programme on Approaches to Address Loss and Damage', UN Doc. FCCC/SBI/2012/MISC.14, 2 Oct. 2012, p. 14 (noting the need to 'reaffirm, rather than duplicate, efforts already undertaken to support activities that address loss and damage associated with climate change'). See also 'Warsaw Establishes International Mechanism for Loss and Damage' (2013) 279/280 Third World Resurgence, pp. 15-8.

60 N. 4 above.

61 Decision 2/CP.19, n. 7 above, recital 5 (emphasis added). 
transfer unavoided loss and damage, including through a financial mechanism based on causal responsibility.

\subsection{Migration as a Source of Loss and Damage for the Migrants}

Human mobility can also be considered as a source of loss and damage suffered by the migrants themselves. Such loss and damage can be endured through any form of migration: uprooted populations are generally more vulnerable to human rights abuses such as systematic discrimination and economic exploitation. Harm can be substantial when and where the migrant human rights are not effectively protected. States have not generally shown great enthusiasm for the protection of the rights of international migrants, in particular undocumented individuals, and the protection of non-citizens (who generally do not vote) remains a challenge for democracies. ${ }^{62}$ Great loss and damage can also result from unprepared mass migration, when protection capacities are exceeded, and vulnerable populations (for example, on account of gender, age, minority status, indigenousness, or disabilities) are displaced.

A brief review of international practice points at noteworthy precedents where migration was recognized as a source of harm, the wrongful infliction of which entailed international responsibility. Thus, there is well-established state practice of providing compensation measures when foreign citizens were expelled in violation of international standards of protection. ${ }^{63}$ On this basis, Poland and Czechoslovakia addressed mutual claims for reparation for the expulsion of foreign nationals in the context of post-Second World War border disputes. ${ }^{64}$ Similarly, the UN Compensation Commission, established by the UN Security Council to address claims related to 'any direct loss, damage ... or injury' ${ }^{65}$ arising from Iraq's invasion of Kuwait, provided compensation to those forced to leave or unable to return to these countries during the conflict. ${ }^{66}$ In each case, compensation for displacement per se was recognized as an additional element to compensation for any other loss or damage (such as loss of property) suffered as a result of displacement.

62 See, e.g., International Convention on the Protection of the Rights of All Migrant Workers and Members of their Families, New York, NY (US), 18 Dec. 1990, in force 1 July 2003, available at: https://treaties.un.org/Pages/ViewDetails.aspx? src=IND\&mtdsg_no=IV-13\&chapter=4\&lang=en (recital 10: 'Considering the situation of vulnerability in which migrant workers and members of their families frequently find themselves owing, among other things, to their absence from their state of origin and to the difficulties they may encounter arising from their presence in the State of employment'); D. Weissbrodt, The Human Rights of Non-Citizens (Oxford University Press, 2008), p. 241; F. Crépeau, 'Dealing with Migration: A Test for Democracies' (2010) 35 Refugee Watch, pp. 37-50.

63 See, e.g., the many cases gathered in M. Whiteman, Damages in International Law I (US Government, 1937), pp. 418-83.

64 Agreement between the Polish People's Republic and the Czechoslovak Republic concerning the Settlement of Outstanding Property Matters, Prague (Czechoslovakia), 29 Mar. 1958, in force 9 Jan. 1959, Art. 5(1), available at: https://treaties.un.org/doc/Publication/UNTS/Volume\%20340/v340.pdf.

65 UN SC Resolution 687, UN Doc. S/RES/687, 8 Apr. 1991, para. 16, available at: http://www.un.org/ Depts/unmovic/documents/687.pdf.

66 Decision 7 of the Governing Council of the UN Compensation Commission taken during its Third Session, 'Criteria for Additional Categories of Claims', UN Doc. S/AC.26/1991/7/Rev.1, 17 Mar. 1992, para. 6(b), available at: http://www.uncc.ch/sites/default/files/attachments/S-AC.26-DEC \%207\%20-\%20Rev\%201\%20\%5B1992\%5D.pdf. 
In the same vein, some documents produced before the UNFCCC Workstream on Loss and Damage construed migration as a source of harm for the migrants - particularly in scenarios of forced migration such as disaster-induced displacements ${ }^{67}$ and resettlement induced by response measures such as the construction of dams ${ }^{68}$ - and called for efforts to reduce such harm. A submission from the Climate Action Network, a coalition of 550 NGOs, described resettlement and migration as 'extreme responses for affected communities' ${ }^{69}$ Overall, a technical paper produced by the UNFCCC Secretariat included a relatively extensive analysis of the non-economic loss and damage caused by 'displacement', approached as forced mobility, as comprising in particular 'a loss of security (including legal rights) and agency (the ability to control one's location and livelihood)'. ${ }^{70}$ The paper highlighted that '[i]n the same way that a loss of health is a type of loss and damage because health is important to well-being, displacement is a type of loss and damage because security and agency, which are lost due to displacement, are important to well-being, ${ }^{71}$ In addition to displacement 'as a (non-economic) type of loss and damage in itself', the technical paper acknowledged the existence of 'losses from displacement', consisting of 'economic losses of displacement, such as the loss of possession, and indirect non-economic losses, such as loss of health and social networks' ${ }^{72}$

This possible framing of (forced) migration as a source of loss and damage for the migrants themselves should not refute the possible benefits of migration as a normal process of social adjustment. Loss and damage arise mostly not from migration in and of itself but from the circumstances in which it occurs. Thus, their treatment en route and at the destination plays a great role in exacerbating or mitigating the 'plight' of migrants. Loss and damage are likely to arise because of inadequate legal or institutional frameworks which either fail to offer effective protection to migrants, or try to oppose migration through non-liberal measures. ${ }^{73}$ It is noteworthy that the Paris Agreement explicitly acknowledges state obligations to respect and protect migrant human rights. ${ }^{74}$ Going further, it must be kept in mind that what is regrettable about forced migration is not the migration itself so much as the factors that force individuals to flee (such as from war, persecution, or adverse environmental conditions).

\subsection{Migration as a Source of Loss and Damage for Other Concerned Communities}

Human mobility can sometimes be seen as inflicting loss and damage on other stakeholders, in particular host states or communities. It must be kept in mind that

67 UNFCCC Literature Review, n. 6, para. 195.

68 Ibid., paras 139, 162(b).

69 Climate Action Network, 'Submission on the Work Programme on Loss and Damage', 22 Aug. 2011, p. 2, available at: http://www.climatenetwork.org/sites/default/files/CAN_submission_loss_and_damage_Aug2011.pdf (CAN 2011 Submission).

70 UNFCCC Technical Paper, n. 17 above, para. 83.

71 Ibid.

72 Ibid (emphasis added).

73 The violence inherent in migration control was elegantly critiqued in J. Carens, 'Aliens and Citizens: The Case for Open Borders' (1987) 49(2) The Review of Politics, pp. 251-73, at 251 ('Borders have guards and the guards have guns').

74 Decision 1/CP.21, n. 5 above, Annex, recital 11. 
certainly most migration scenarios unfold for the net benefit of host communities, given the contribution of migrants to the economic, social and cultural life of these communities. ${ }^{75}$ Yet, the sudden arrival of large numbers of individuals may incur loss and damage to host communities and other stakeholders. Assistance and protection measures generate expense and divert resources, possibly straining public services and environmental resources, especially within poor countries or communities. In extreme cases, mass arrivals may affect the availability of basic commodities and threaten public order or political institutions. ${ }^{76}$ Despite some international humanitarian assistance, most of the economic and non-economic burden of hosting large populations of migrants - refugees, in particular - has generally been sustained by host communities themselves.

International practice has sometimes recognized loss and damage suffered by host communities. For instance, the 1951 Convention relating to the Status of Refugees recognizes that 'the grant of asylum may place unduly heavy burdens on certain countries'. ${ }^{77}$ States have made (largely unsuccessful) efforts to define ways in which to share the 'burden' or 'responsibility' for the protection of refugees. ${ }^{78}$ Instead, large migrations have sometimes been constructed as a threat to the security of the destination states. Thus, since the end of the Cold War, the UN Security Council has repeatedly considered that a 'massive flow of refugees towards and across international frontiers' could constitute a threat to international peace and security. ${ }^{79}$ From the same perspective, the Secretary General of the North Atlantic Treaty Organization (NATO) tried to justify armed intervention in Kosovo by presenting refugees from Kosovo as a threat to regional stability. ${ }^{80}$ More fundamentally, Western states generally pursue an objective of controlling migration from the developing world - something often qualified as a 'non-entrée strategy' - which derives from the prevalent, although highly questionable, framing of migration as a burden, rather than an opportunity, for the host state. ${ }^{81}$

75 See, e.g., M. Clemens, 'Economics and Emigration: Trillion-Dollar Bills on the Sidewalk?’ (2011) 25(3) Journal of Economic Perspectives, pp. 83-106.

76 See, e.g., M. Czaika, 'A Refugee Burden Index: Methodology and its Application' (2005) 2(2) Migration Letters, pp. 101-25; M. Barutciski \& A. Suhrke, 'Lessons from the Kosovo Refugee Crisis: Innovations in Protection and Burden-Sharing' (2001) 14(2) Journal of Refugee Studies, pp. 95-134; J. Alix-Garcian \& D. Saah, 'The Effect of Refugee Inflows on Host Communities: Evidence from Tanzania' (2010) 24(1) The World Bank Economic Review, pp. 148-70.

77 Geneva (Switzerland), 28 Jul. 1951, in force 22 Apr. 1954, recital 5, available at: http://www.unhcr. org/3b66c2aa10.html.

78 See generally M. Gottwald, 'Burden Sharing and Refugee Protection', in E. Fiddian-Qasmiyey et al. (eds), The Oxford Handbook of Refugee and Forced Migration Studies (Oxford University Press, 2014), pp. 525-37. See also the Convention Governing the Specific Aspects of Refugee Problems in Africa, 10 Sept. 1969, in force 20 June 1974, Art. 2(4), available at: http://www.refworld.org/docid/ 3ae6b36018.html.

79 UN SC Resolution 688 (1991), UN Doc. S/RES/0688 (1991), 5 Apr. 1991. available at: http://fas.org/ news/un/iraq/sres/sres0688.htm. See generally E. Mogire, Victims as Security Threats: Refugee Impact on Host State Security in Africa (Ashgate, 2013), pp. 24-6.

80 Lord Robertson of Port Ellen, Secretary General of NATO, 'Kosovo One Year On: Achievement and Challenge', NATO, 2000, p. 5, available at: http://www.nato.int/kosovo/repo2000/report-en.pdf.

81 See, in particular, B.S. Chimni, "The Birth of a "Discipline": From Refugee to Forced Migration Studies' (2009) 22(1) Journal of Refugee Studies, pp. 11-29. 
There is not always a clear distinction between claims for compensation for loss and damage suffered by the migrants themselves or by the host communities. In the Luxembourg Agreement, the Federal Republic of Germany accepted that it would make recompense to Israel for 'the heavy burden of resettling so great a number of uprooted and destitute Jewish refugees from Germany and from territories formerly under German rule'. ${ }^{82}$ Diplomatic protection could not be invoked as a basis for compensation as Israel, which was created in 1948, had no personal jurisdiction during the flight of many Jews from Europe. A reference to the 'burden of resettling' refugees was an alternative way of justifying a similar scheme of reparation, not directly in relation to the loss and damage suffered by Jewish refugees but to the costs encountered by the state of Israel in resettling them. Similar academic arguments have been made in relation to states that wrongfully cause large movements of populations, either from their own territory $^{83}$ or from overseas territory on which they intervene militarily or otherwise. ${ }^{84}$

Within the UNFCCC Workstream on Loss and Damage, the interests of host communities and other stakeholders have also been considered. In particular, a technical paper prepared by the UNFCCC Secretariat, which AOSIS cited with approbation, highlighted the harm that developed countries would incur, including through an increase in South-North migration, if they failed to support mitigation or adaptation in the most vulnerable states. ${ }^{85}$ Similarly, in the run-up to the 2015 Paris conference (COP-21), several NGOs called upon the parties to the UNFCCC 'to ensure each affected country share equitably the consequences of populations' displacements' ${ }^{86}$ This argumentative utilization of the spectre of international migration could raise awareness and support for mitigation and adaptation, but it also entails significant political risks. Excessively insisting on the adverse impacts of (international) migration for the host communities tends to reinforce a lurking suspicion, if not a frank hostility, towards migration. This diffuse xenophobia tends to foster support for strategies of 'migration management' which, by trying to deter migrants from powerful states, could hinder migration as a form of adaptation and thus exacerbate loss and damage. ${ }^{87}$

These political risks are illustrated by the role played by the International Organization for Migration (IOM). By way of contrast with the Office of the United Nations High Commissioner for Refugees (UNHCR), the IOM is not a UN agency and it does not have a clear protection mandate. ${ }^{88}$ The IOM's mission is to

82 Luxembourg Agreement between Germany and Israel, Luxembourg, 10 Sept. 1952, in force 27 Mar. 1953, recital 3, available at: https://treaties.un.org/doc/Publication/UNTS/Volume\%20162/volume162-I-2137-English.pdf.

83 See, e.g., F.Z. Giustiniani, 'The Obligations of the State of Origin of Refugees: An Appraisal of a Traditionally Neglected Issue' (2015) 30 Connecticut Journal of International Law, pp. 171-208, at 173-6. L. Fabius and Ban Ki Moon, signed by Care International and other NGOs), Sept. 2015, available at: http://climateandcrises.com/open-letter.

87 See generally the review in Mayer, n. 14 above.

88 IOM Council, 'IOM Strategy', Resolution 1150 (XCIII), MC/INF/287, 9 Nov. 2007, Annex, Pt 1, para. 9, note, available at: https://www.iom.int/jahia/webdav/shared/shared/mainsite/about_iom/docs/ res1150_en.pdf (IOM Strategy Document). 
'enhance the humane and orderly management of migration' ${ }^{89}$ by assisting states on a project by project basis. ${ }^{90}$ The IOM has actively contributed to the Workstream on Loss and Damage, ${ }^{91}$ where it advocated 'assisting and protecting vulnerable mobile populations' and 'promoting migration as an adaptation and livelihood strategy'.92 Yet, the IOM's actions on the ground have remained contingent on the priorities of its parties and funders. Beyond an important role in providing operational assistance in response to sudden displacements, ${ }^{93}$ the IOM's operations in the states most vulnerable to climate change impacts tend to put a strong emphasis on in situ adaptation and 'resilience', rather than on promoting migration or protecting migrants. $^{94}$

The same priorities seem to be favoured by the decision of the Paris climate change conference (COP-21) to establish a task force that will promote 'approaches to avert, minimize and address displacement related to the adverse impacts of climate change'. ${ }^{95}$ This provision was drafted apparently in parallel with Article 8 of the Paris Agreement, whereby states 'recognize the importance of averting, minimizing and addressing loss and damage associated with the adverse effects of climate change'. ${ }^{96}$ Yet, the construction of displacement as a form of loss and damage deprives the populations affected by adverse environmental conditions of an essential form of adaptation if the causes of (forced) displacement are not addressed. Approaches are needed to protect populations from the adverse impacts of climate change rather than to prevent them from seeking shelter elsewhere.

\section{APPROACHES TO ADDRESS MIGRATION ASPECTS OF LOSS AND DAMAGE}

Framing human mobility in relation to loss and damage associated with climate change impacts has important implications. The political utilization of fears of climate refugees perceived as a source of harm for host communities has serious drawbacks. A conscious balancing of the three framings detailed above - as a way to reduce loss and damage and a possible source of loss and damage for either migrants themselves or the surrounding communities - could help to devise more adequate approaches to address loss and damage. Building on these bases, this section explores

89 IOM Strategy Document, ibid., Pt 1, para. 3.

90 Ibid., para. 3.

91 See, e.g., references listed at n. 49 above.

92 'Input of the IOM to a Review of Existing Institutional Arrangements and Measures in Addressing Loss and Damage Conducted by the UNFCCC Secretariat', 2013, p. 2, available at: http://unfccc.int/ files/adaptation/cancun_adaptation_framework/loss_and_damage/application/pdf/iom.pdf.

93 See, e.g., IOM Migration Crisis Operational Framework, MC/2355, 15 Nov. 2012, available at: https://www.iom.int/files/live/sites/iom/files/What-We-Do/docs/MC2355_-_IOM_Migration_Crisis_ Operational_Framework.pdf.

94 See generally IOM, 'Migration Initiatives 2015: Regional Strategies, Migrants and Cities', 2014, e.g. pp. 63 (Namibia) and 187 (Marshall Islands), available at: http://publications.iom.int/system/files/pdf/ migration_initiatives2015.pdf.

95 Decision 1/CP.21, n. 5 above, para. 50 (emphasis added).

96 Ibid., Annex, Art. 8.1 (emphasis added). 
possible approaches to address migration aspects of loss and damage beyond the current mandate of the WIM (research and advocacy), either through top-down governance responses or diverse forms of remedial obligations.

\subsection{Governing Climate Migration}

Various proposals for norms, policies and programmes have been submitted to the UNFCCC Workstream on Loss and Damage in relation to human mobility. A general distinction can be drawn between proposals that emphasize 'managing' migration and those that put a clearer stress on the need to protect migrants. The proposals that aim to manage migration are fuelled generally by the perception of migration as a potential source of loss and damage for the migrants themselves or for other stakeholders. For instance, 'provisions for establishing a climate change displacement coordination facility' were proposed for inclusion, among other 'institutional arrangements' to address loss and damage, in some negotiation instruments of the second session of the ADP (2014-15). ${ }^{97}$ This facility, in particular, would seek to 'assist ... in providing organized migration and planned relocation' 98 Such proposals, are not clearly distinct from adaptation projects: they fundamentally aim to reduce loss and damage through migration as adaptation.

By contrast, proposals developed to protect rights or otherwise address the needs of migrants themselves are built on an understanding of migration as a normal social phenomenon through which individuals, households and communities respond to the changes they encounter, including as a consequence of various impacts of climate change. Emphasis is placed accordingly on the need for adequate legal and institutional frameworks to ensure that migration occurs in the best possible conditions, especially from the migrants' perspective, taking into account particular factors of vulnerability. Thus, a submission by the International Federation of the Red Cross and Red Crescent Societies (IFRC) notes the importance of taking climate change into consideration, within a holistic approach of humanitarian and development actions, in order to 'tackle migrants' vulnerabilities'. 99 In its broader strategy to which its submission refers, the IFRC highlights the need for 'providing help to vulnerable migrants who are in need of assistance and protection, reducing the risks that they face along their migration routes, empowering them in their search for long-lasting and appropriate solutions, and promoting wider understanding of migrants' rights and their social inclusion within host communities' ${ }^{100}$

97 Decision 1/CP.20, 'Lima Call for Climate Action', 11 Dec. 2014, para. 33.3, available at: https://unfccc.int/files/meetings/lima_dec_2014/application/pdf/auv_cop20_lima_call_for_climate_action. pdf.

98 Ibid.

99 Input of the IFRC to a review of existing institutional arrangements and measures in addressing loss and damage conducted by the UNFCCC Secretariat (2013), available at: http://unfccc.int/files/ adaptation/cancun_adaptation_framework/loss_and_damage/application/pdf/ifrc.pdf (IFRC Input).

100 IFRC, 'Strategy 2020: Saving Lives, Changing Minds', 2010, p. 19, available at: http://www.ifrc.org/ Global/Publications/general/strategy-2020.pdf. A similar approach was developed in 'Report by the United Nations Special Rapporteur on the Human Rights of Migrants', n. 54 above. 
Proposals have also been made, generally outside the UNFCCC, for the adoption of a specific international instrument for the protection of individuals displaced within or across international borders as a consequence of climate change impacts. ${ }^{101}$ Since 2012, the Nansen Initiative of the governments of Norway and Switzerland has conducted a series of global and regional consultations for the development of 'a protection agenda for people displaced across borders in the context of disasters and the effects of climate change'. ${ }^{102}$ Similarly, the Peninsula Principles on Climate Displacement within States, elaborated by the NGO Displacement Solutions in 2013, suggest that 'states should develop appropriate laws and policies for loss suffered and damage incurred in the context of climate displacement'. ${ }^{103}$ These proposals face strong opposition from states when they involve or advocate a duty on the part of Western states to host international migrants. ${ }^{104}$ They also raise vexing questions of definition related to the difficulty of attributing individual migrants to weather or climate events (let alone the more general difficulty of attributing such events to climate change), given the strong consensus among migration scholars that environmental factors cannot be understood in isolation from other circumstances. ${ }^{105}$

Overall, it is arguably counterproductive to define additional obligations borne by the states most affected by climate change, rather than defining rights that these states hold against developed nations.

With regard to the protection of migrants in the states concerned, there is no clear reason to distinguish climate migrants from other migrants who encounter similar needs for protection. ${ }^{106}$ The cause of migration (the loss and damage that migration attempts to avoid) is distinct from the cause of the vulnerability of the migrants (the loss and damage suffered as a result of migration). The perception of the impacts

101 See, e.g., F. Biermann \& I. Boas, 'Preparing for a Warmer World: Towards a Global Governance System to Protect Climate Refugees’ (2010) 10(1) Global Environmental Politics, pp. 60-88; CRIDEAU, 'Draft Convention on the International Status of Environmentally Displaced Persons' (2008) 39 Revue de Droit de l'Université de Sherbrooke, pp. 451-505; D. Hodgkinson et al., 'The Hour When the Ship Comes In: A Convention for Persons Displaced by Climate Change' (2010) 36(1) Monash University Law Review, pp. 69-120; B. Docherty \& T. Giannini, 'Confronting a Rising Tide: A Proposal for a Convention on Climate Change Refugees' (2009) 33(2) Harvard Environmental Law Review, pp. 349-403.

102 See the official website of the Nansen Initiative at: https://www.nanseninitiative.org. See also W. Kälin, 'From the Nansen Principles to the Nansen Initiative' (2012) 41 Forced Migration Review, pp. 48-9.

103 Displacement Solutions, 'The Peninsula Principles on Climate Displacement within States', 18 Aug. 2013, Principle 12, available at: http://displacementsolutions.org/wp-content/uploads/2014/12/ Peninsula-Principles.pdf.

104 The proposal for a 'climate change migration coordination facility' was, for instance, strongly opposed by the government of Australia: O. Milman, 'UN Drops Plan to Help Move Climate-Change Affected People', The Guardian, 7 Oct. 2015, available at: http://www.theguardian.com/environment/ 2015/oct/07/un-drops-plan-to-create-group-to-relocate-climate-change-affected-people.

105 Foresight Report, n. 2 above, p. 9, Executive Summary (noting that 'the range and complexity of the interactions between these drivers means that it will rarely be possible to distinguish individuals for whom environmental factors are the sole driver ("environmental migrants")').

106 A. Betts, Survival Migration: Failed Governance and the Crisis of Displacement (Cornell University Press, 2013), p. 17 ('Whether someone's displacement is predominantly attributable to environmental change, state fragility, or livelihoods collapse is unimportant from a human rights perspective'). 
of climate change on migration could serve as a wake-up call for better protection of migrants across the world, and one may hope that it will spur some reforms towards stronger protection policies, although the climate regime is probably not the right forum to address the general protection needs of migrants. ${ }^{107}$

Other proposals for better management of migration or better protection of migrants as part of approaches to address loss and damage raise comparable issues. Here, again, defining the scope of climate migration remains difficult because of the indirect causality at play. Therefore, it is not clear how a 'climate change displacement coordination facility' could adopt a workable definition of its scope of action. On the other hand, putting greater emphasis on some scenarios of climate migration rather than on other migration scenarios featuring analogous human vulnerabilities could result in imposing arbitrary priorities on national authorities and other stakeholders in the allocation of scarce protection resources among different populations. ${ }^{108}$ For these reasons, the IFRC's preference for mainstreaming considerations for climate change impacts within a broader, holistic approach of humanitarian and development actions is certainly commendable. ${ }^{109}$ The occurrence of climate change impacts affecting migration highlights and exacerbates the need for general reforms in international migration governance - with regard to both the management of migration and the protection of migrants, in order to promote migration as a mutually beneficial process - but it does not justify particular policies that would isolate and try to address climate migration as if it were a distinct phenomenon.

\subsection{Remedial Obligations}

Rather than mandating particular responses to loss and damage, some vulnerable states $^{110}$ and NGOs ${ }^{11}$ have long and actively advocated approaches to address loss and damage in terms of causal responsibility. Historically, the bulk of GHG emissions have originated from developed states, the per capita emissions of which remain significantly higher than those of most developing nations. ${ }^{112}$ The principle of 'common but differentiated responsibilities' hints at a recognition of causal responsibility by such states. ${ }^{113}$ The 2010 Cancún Agreements (COP-16)

107 For alternative forms see, e.g., Betts, ibid.; 'Protection of Persons in the Events of Disasters: Text and Titles of the Draft Articles', UN Doc. A/CN.4/L.831, 15 May 2015, available at: http://legal.un.org/ docs/?symbol=A/CN.4/L.831.

108 See generally B. Mayer, 'Environmental Migration in the Asia-Pacific Region: Could We Hang Out Sometime?' (2013) 3(1) Asian Journal of International Law, pp. 101-35.

109 IFRC Input, n. 99 above.

110 AOSIS Nauru Submission, n. 38 above. See also Huq, Roberts \& Fenton, n. 46 above, p. 948 (noting that 'for many developing countries - especially for small island developing states - [compensation] is an important element of the agenda').

111 CAN 2011 Submission, n. 69 above, p. 2 (calling for 'a mandate to explore compensation options for loss and damage caused by climate change').

112 Data on GHG emissions per country can be accessed from the World Resources Institute's Climate Data Explorer, available at: http://cait2.wri.org.

113 See, however, the statement made by the US on Principle 7 of the Rio Declaration on Environment and Development (adopted by UNCED, Rio de Janeiro (Brazil), 3-14 June 1992, UN Doc. A/CONF.151/26/Rev.1 (Vol. I), 14 June 1992, available at: http:/www.un.org/documents/ga/ 
recognized explicitly the historical responsibilities of developed states as a ground for differentiation. ${ }^{114}$

It has been argued elsewhere that a state's excessive GHG emissions constitute a breach of the no-harm principle and entail its responsibility under international law. ${ }^{115}$ At least an analogy can be drawn between climate change responsibility and the customary international law of state responsibility as a reflection of the relevance of a general moral principle of responsibility in the conduct of international relations. Under the Draft Articles on the Responsibility of States for Internationally Wrongful Acts adopted by the International Law Commission (ILC) in second reading in 2001, a responsible state is under an obligation to make full reparation for injury caused by its fault. ${ }^{116}$ Reparation should be made through restitution, compensation and satisfaction. $^{117}$

Yet, the issue of direct causality for indirect climate change impacts remains a problematic concept in international law, and causal attribution is an important source of difficulty in drawing an analogy between loss and damage and the principle of responsibility. The ILC's authoritative analysis of the law of state responsibility concluded that if an 'injury caused by the international wrongful act' does not need to be the 'direct' or 'proximate' consequence of this act, it needs at least to be not too 'remote' or 'consequential'. 118 This condition is obviously more demanding than the vague reference to loss and damage 'associated with' climate change impacts. Discussions on loss and damage have not generally placed much emphasis on the distinction between 'human caused' and 'tough luck' physical events. ${ }^{119}$ A probabilistic event attribution framework, which is being developed, could soon make it possible to assess the extent to which particular physical events are 'caused by' anthropogenic climate change. ${ }^{120}$ Even then, however, it would remain difficult to attribute particular social responses to the physical events in question. Migration, it needs to be rehearsed, can rarely be convincingly attributed to a physical event in isolation from a broader social, economic, political and cultural context; the importance of contextual elements makes loss and damage suffered in relation to migration a rather 'remote' and 'consequential' form of injury.

Moreover, the perspective of loss and damage as a reflection of international responsibility raises difficult questions relating to the characterization of the 'injury'

conf151/aconf15126-1annex1.htm) in UNCED Report: Proceedings of the Conference, UN Doc. A/CONF.151/26/Rev.1(Vol. II) (1992), p. 17 ('The United States does not accept any interpretation of principle 7 that would imply a recognition or acceptance by the United States of any international obligations or liabilities, or any diminution in the responsibilities of developing countries').

114 Decision 1/CP.16, n. 4 above, recital 2, para. 36. See also UNFCCC, n. 3 above, recital 4.

115 See, e.g., B. Mayer, 'State Responsibility and Climate Change Governance: A Light Through the Storm' (2014) 13(3) Chinese Journal of International Law, pp. 539-75; C. Voigt, 'State Responsibility for Climate Change Damages' (2008) 77 Nordic Journal of International Law, pp. 1-22.

116 Draft Articles on the Responsibility of States for Internationally Wrongful Acts, 2001, Art. 31, available at: http://legal.un.org/ilc/texts/instruments/english/commentaries/9_6_2001.pdf.

117 Ibid., Art. 34.

118 Ibid., commentary to Art. 31, n. (10).

119 See discussion in Hulme, n. 9 above, p. 507.

120 See, e.g., Pall et al., n. 9 above. 
and the possible forms of 'reparation'. At first sight, the injury could presumably include any loss and damage, inasmuch as a sufficient causal link can be established with excessive GHG emissions. Migration can reduce loss and damage, while loss and damage can also result from migration, whether suffered by migrants or by other stakeholders. Public expenditure to reduce loss and damage, either by promoting migration or by protecting potential or actual migrants and other stakeholders, is also a likely ground for reparation. ${ }^{121}$

Proposals nevertheless have been made for approaches to address migration as a matter of international responsibility. ${ }^{122}$ In the law of state responsibility, by analogy, reparation must be made through restitution, compensation or satisfaction, either singly or in combination. ${ }^{123}$ Compensation is the most common form of reparation, and examples discussed above have led to compensation for loss and damage suffered by individuals ${ }^{124}$ and by host states ${ }^{125}$ in the context mainly of forced migration. However, because they result from diplomatic negotiation rather than adjudication, these examples give little indication of the possible basis for the economic valuation necessary for compensating for non-economic loss and damage. The assessment of loss and damage associated with climate change impacts, in particular those related to migration, should certainly take into account contributory factors. Accordingly, compensation would represent only a tiny fraction of the actual loss and damage.

Alternative proposals focus on original mechanisms through which in-kind assistance would be provided as a form of reparation. Support for such proposals can be found in a reference in the Cancún Agreement (2010) to 'measures to enhance ... coordination and cooperation with regard to climate change induced displacement, migration and planned relocation'. ${ }^{126}$ Saleemal Huq, an influential advocate of the loss and damage agenda, has thus called for 'institutional arrangements to address loss and damage' through providing 'guidance and support' to developing states, including devising 'risk transfer and risk retention measures, as well as policies to promote migration and facilitate resettlement'. ${ }^{127}$ Others have argued that a loss and damage mechanism covering some of the 'costs of relocating climate-changedisplaced communities has the potential to ... support longer term risk reduction strategies'. ${ }^{128}$ To this end, the proposal of least developed countries for a Climate

121 Draft Articles on the Responsibility of States, n. 116 above, commentary to Art. 36, n. (5).

122 See, e.g., the informal note by the Co-Chairs, 'Scenario Note on the Tenth Part of the Second Session of the Ad Hoc Working Group on the Durban Platform for Enhanced Action', ADP.2015.4.Informal Note, 24 July 2015, p. 32, on a proposal for the creation of a mechanism to 'establish procedures for coordinating compensation measures', available at: http://unfccc.int/resource/docs/2015/adp2/eng/ 4infnot.pdf.

123 Draft Articles on the Responsibility of States, n. 116 above, Art. 34.

124 See references cited in nn. 63-66 above.

125 See n. 82 above.

126 Decision 1/CP.16, n. 4 above, para. 14(f).

127 Huq, Roberts \& Fenton, n. 46 above, p. 948.

128 I. Millar, C. Gascoigne \& E. Caldwell, 'Making Good the Loss: An Assessment of the Loss and Damage Mechanism under the UNFCCC Process', in M. Gerrard \& G. Wannier (eds), Threatened 
Change Coordination Facility has called for 'support for emergency relief, assistance [and] compensation measures'. ${ }^{129}$

Scholars have imagined yet more ambitious (but also, generally, less realistic) forms of assistance in lieu of reparation. One such proposal is that developed nations commit to host international migrants from the states most severely affected by climate change, possibly on the basis of a quota reflective of responsibility criteria (such as historical and present GHG emissions). ${ }^{130}$ Alternatively, a status of 'climate refugee' could be made applicable to internal as well as international migrants, with an obligation for developed states to contribute, logistically or financially, to the protection of those populations remaining in developing states. ${ }^{131}$ Lastly, territories could be ceded or made available to populations in need of resettlement, in particular as a response to the total loss of inhabitable territory that some low-lying small-island developing states may suffer in the coming decades. ${ }^{132}$ These proposals are not entirely isolated from broader reflections on global migration governance. Some migration scholars have suggested a justification for the resettlement of refugees more generally on the basis of the responsibility of states - in particular, Western states which cause forced migrations abroad, either through military intervention ${ }^{133}$ or, more generally, through 'enforcing an international economic and political order that causes underdevelopment and conflict'. ${ }^{134}$

The provision of visas, status, or territory to climate migrants has some commonality with restitution, as it aims essentially at the restoration of decent conditions of life for individuals affected by climate change impacts. ${ }^{135}$ However, such forms of assistance involve a much greater degree of political interference than does restitution (defined as efforts to re-establish the status quo ante) ${ }^{136}$ or through compensation (the transfer of fungible value, usually money, of which the injured state may dispose as is seen fit). ${ }^{137}$ The provision of in-kind assistance, support, or a fortiori guidance would certainly affect the ability of the populations and states

Island Nations, Legal Implications of Rising Seas and a Changing Climate (Cambridge University Press, 2013), pp. 433-72, at 435.

$$
\text { Sociol }
$$
Cogy, pp. 13-34, at 18. See also J. Souter, 'Towards a Theory of Asylum as Reparation for Past Injustice' (2014) 62(2) Political Studies, pp. 326-42; J. Souter, 'Durable Solutions as Reparation for the Unjust Harms of Displacement: Who Owes What to Refugees?' (2014) 27(2) Journal of Refugee Studies, pp. 171-90.

135 Cf. Souter, 'Durable Solutions as Reparation', ibid., p. 175.

136 Draft Articles on the Responsibility of States, n. 116 above, Art. 35.

137 Ibid., Art. 36 and commentary to Art. 36, n. (4). Cf. Souter, 'Durable Solutions as Reparation', n. 134 above, p. 176. 
in question to determine, through their regular political processes, the course of action that they wish to take. Replicating the experience of colonialism, this hindrance to the development of functional political institutions could be used as an excuse for further foreign political interference. Such interference is particularly problematic when it concerns the highly politicized field of migration governance, which involves complex trade-offs between collective identity and individual opportunities, and more generally local decisions about individual and collective projects. Within the margin allowed by international human rights standards, domestic and local responses to loss and damage - including decisions as to whether and how to migrate - need to be decided by the populations concerned, not by international organizations or foreign donors.

In these circumstances, in-kind assistance provided by international or foreign institutions in response to the influence of climate change on migration would be likely to undermine the best interests of their recipients. Top-down normative responses to climate migration, in particular, ignore the great diversity of climate change-related migration scenarios and the need for responses that take local circumstances into account. ${ }^{138}$ More specifically, advocacy for the protection of so-called climate migrants could result in an arbitrary allocation of scarce financial and other resources necessary to implement effective human rights protection (especially within states the protection resources of which will increasingly be strained by the adverse impacts of climate change). This would disadvantage the populations 'trapped in place' (who lack the resources necessary to migrate) ${ }^{139}$ and those, not necessarily any less vulnerable, who migrate for reasons unrelated to climate change impacts. Above all, allowing international or foreign institutions to coordinate, support or guide migration policies in developing states would create one more opportunity for Western states to impose their own agendas in an area of governance intrinsically connected with the determination of national development priorities. The strongest emphasis is likely not to be placed on the promotion of mutually beneficial migration or on the protection of the rights of migrants, but rather on the protection of the most powerful states against the perceived threats of massive 'flows' of climate refugees.

\section{CONCLUSION}

Human mobility is often a fruitful social process through which individuals, households and communities adapt to changes in circumstances. It can also be a source of harm, either for the migrants themselves, most obviously in the case of resettled or evacuated populations, or sometimes for other stakeholders, in particular the host communities in cases of mass arrivals. Above all, however, human mobility is

138 R. Hil, 'Climate Change, Population Movements and Governance: Case Studies in Response Mechanisms', in T. Cadman (ed.), Climate Change and Global Policy Regimes: Towards Institutional Legitimacy (Palgrave Macmillan, 2013), pp. 187-201, at 189.

139 For a similar argument against an instrument for the protection of internally displaced persons, see the remarks of J. Hathway, 'Discussion' (1996) 90 Proceedings of the Annual Meeting of the American Society of International Law, pp. 558-84, at 562. 
part of the processes through which individual and collective identities are constructed. Governments are obligated, under international human rights law, to protect populations within their jurisdiction and to cooperate in the protection of populations abroad - including migrants, who are often more vulnerable than other populations. The UNFCCC Workstream on Loss and Damage is likely to unveil many shortcomings in global migration governance, and it could play an important role in raising awareness of the need for more genuine international cooperation for the protection of the human rights of all.

Yet, this article has questioned the opportunity of allowing the UNFCCC Workstream on Loss and Damage to define responses to climate change impacts, in particular with regard to human mobility. Migration decisions taken at all levels (individuals, households, communities, and states) relate to highly value-loaded decisions. Such choices as between adaptation in situ and migration are closely connected to development strategies, the determination of which has long been advocated as the fundamental preserve of national governments. ${ }^{140}$ Those developing states most vulnerable to the adverse impacts of climate change need financial support and capacity building at least as urgently as policy support: those states ought to be able to define, through their own political processes informed but not constrained by an open transnational debate, the best way to pursue their own interests. Approaches to address loss and damage, which include financial support and promoting capacity building, should as far as possible refrain from interfering with the domestic political processes of these states, especially in the sensitive area of migration governance.

140 See generally UNGA Resolution, 'Declaration on the Right to Development', UN Doc. A/Res/41/128, 4 Dec. 1986, available at: http://www.un.org/documents/ga/res/41/a41r128.htm. 